\title{
Performance of Fig (Ficus carica L.) Under Different Planting Densities
}

\author{
R. Chithiraichelvan, Reju M. Kurian*, Chandrakant M. Awachare and R.H. Laxman \\ Indian Institute of Horticultural Research, Hessaraghatta Lake, Bengaluru-560 089, India \\ *Corresponding author
}

\begin{tabular}{|c|c|}
\hline & A B S T R A C T \\
\hline & \multirow{6}{*}{$\begin{array}{l}\text { A field trial conducted from } 2011 \text { to } 2015 \text { to study the growth, physiology, fruit yield and } \\
\text { quality of fig (Ficus carica L.) cultivars Deanna and Poona under tree densities of } 1000 \text {, } \\
800,666,571 \text { and } 500 \text { plants per hectare indicated that high density planting with } 1000 \text { or } \\
800 \text { plants per hectare was superior to other planting densities for maintaining tree vigour } \\
\text { and fruit yield under continuous cropping during the initial orchard years. With decrease in } \\
\text { tree densities, growth characters like tree height, shoot length, canopy spread, leaf number } \\
\text { and trunk circumference declined gradually which was more pronounced under } 500 \text { plants } \\
\text { per hectare. The gas exchange parameters (photosynthesis rate, stomatal conductance and } \\
\text { transpiration) also declined with tree densities. The per cent PAR interception by the } \\
\text { canopy that ranged from } 79.37 \text { to } 86.63 \% \text { did not differ significantly among the } \\
\text { treatments. There was no difference in fruit quality attributes like TSS and acidity among } \\
\text { the trees grown at the different planting densities. High density planting of fig varieties } \\
\text { Poona and Deanna at } 1000 \text { plants per hectare with initial training of trees to open centre } \\
\text { frame work and annual pruning of previous season's shoots to the basal six nodes during } \\
\text { September is found promising for considerable enhancement in fruit productivity during } \\
\text { the initial six orchard years by } 2.5 \text { and } 2.0 \text { times respectively under the mild tropical, semi- } \\
\text { arid conditions. }\end{array}$} \\
\hline $\begin{array}{l}\text { Ficus carica, } \\
\text { Planting distance, } \\
\text { Tree vigour, } \\
\text { Yield. }\end{array}$ & \\
\hline Article Info & \\
\hline $\begin{array}{l}\text { Accepted: } \\
29 \text { May } 2017\end{array}$ & \\
\hline $\begin{array}{l}\text { Available Online: } \\
10 \text { June } 2017\end{array}$ & \\
\hline & \\
\hline
\end{tabular}

\section{Introduction}

The common fig (Ficus carica L.) is a subtropical, deciduous fruit tree belonging to the Eusyce subgenus of the Moraceae (mulberry) family, cultivated in most Mediterranean-type climates (Flaishman et al., 2008). Fig is considered nutritionally important owing to its richness in vitamins, minerals, antioxidant and medicinal properties (Nath et al., 2008). Despite possibly being the oldest cultivated fruit species (Brown, 1994), lack of scientific information pertaining to production practices limits its acreages (Botti, 2003). Fig being well adapted to high temperatures and low water regimes, has traditionally been cultivated in marginal soils under rain-fed conditions with very little improved cultural practices. Nowadays, its cultivation is increasingly practiced under irrigation (Melgarejo, 2006) along with different agro-techniques that increase both fruit yield and quality (Erez et al., 2003). In India, its cultivation is gaining importance recently not only for local consumption, but also as a commercial crop, because of its low input requirements and high economic value. Figs could be an attractive option to gradually replace some of the traditional crops with higher water requirement in the arid and semiarid regions; but a major limitation to increase the area and production of this crop in India is 
lack of scientific information for its commercial cultivation.

Optimum tree densities along with appropriate canopy management involving training and pruning facilitates better utilization of incident solar radiation and increase in bearing surface per unit land area leading to higher productivity, fruit quality and profitability in many fruit crops (Iyer and Kurian, 2006). A few attempts have been made to relate this concept to fig (Kumar et al., 2014; Hosomi et al., 2013; Mano et al., 2011). The light interception by the tree canopy is determined by tree spacing, canopy density and height (Jackson, 1980). Due to variations in light intensity in different parts of the tree crown, the photosynthesis within the crown is expected to decrease rapidly with increasing depth of foliage (Kozlowski, 1992). Thus, the light availability and photosynthetic rate of leaves positioned at different levels in the tree canopy under higher density planting system is very important. Nevertheless, as the fruits are borne in the axils of current season's shoot, maintaining adequate shoot vigour with sufficient number of leaves is also important to get good fruit yield in fig. Keeping these in view, a field experiment was carried out to find out the effect of planting density on growth and fruiting of fig cultivars Deanna and Poona.

\section{Materials and Methods}

The study was conducted at ICAR-Indian Institute of Horticultural Research, Bengaluru that enjoys mild tropical, semi-arid climate for five years from 2011 to 2015 in commercially important fig cultivars Deanna and Poona under randomized block design with five treatments replicated four times. Trees selected were of uniform age, planted in 2008 and trained to open center, grown at five different intra-row spacing viz. $\mathrm{T} 1=2.0 \mathrm{~m}$,
$\mathrm{T} 2=2.5 \mathrm{~m}, \mathrm{~T} 3=3.0 \mathrm{~m}, \mathrm{~T} 4=3.5 \mathrm{~m}$ and $\mathrm{T} 5=$ $4.0 \mathrm{~m}$ with a common row-to-row distance of $5.0 \mathrm{~m}$ to accommodate $1000,800,666,571$ and 500 trees per hectare respectively. During the experiment, all the previous season's shoots in these plants were annually pruned back to six basal nodes in September. Observations on leaf number, shoot length and intermodal length were recorded at 60 days from pruning. Observations on plant height, trunk circumference and canopy spread (north to south and east to west) were recorded during fruiting stage. Gas exchange characteristics, photosynthesis rate $(\mathrm{A})$, transpiration rate $(\mathrm{E})$ and stomatal conductance $\left(g_{s}\right)$ were recorded using Portable Photosynthesis System (model LC Pro, ADC, UK) between 9.30 to 11.30 am. These observations were recorded at vegetative and fruit development stages, in five replicates in the fully expanded leaves which were fully exposed, partially exposed and completely shaded in the canopy. Number and weight of fruits per tree were recorded at each harvest; from which fruit yields per hectare were computed. Total soluble solids (TSS) and titratable acidity (TA) were determined in ten randomly selected fruits per treatment in each replication. TSS was estimated using Hand Refractometer in ${ }^{\circ} \mathrm{Brix}$ at $20^{\circ} \mathrm{C}$ and TA by AOAC (1990) method using phenolphthalein as indicator. Analyses of variance and F-test were employed for the interpretation of results.

\section{Results and Discussion}

\section{Vegetative growth}

The post pruning shoot emergence was faster in younger than older trees. Differences in shoot length were not significant among the different treatments in both Poona and Deanna fig (Tables 1 and 2) which is in agreement with an earlier finding on the effect of spacing and pruning on Deanna fig (Kumar et al., 2014). The mean tree height, canopy 
spread and trunk circumference over the five year period were generally higher under higher tree densities of 1000 and 800 trees per hectare than lower tree densities, more so in the vigorous Poona cultivar than the less vigorous Deanna, as evident from tables 1 and 2. Mano et al., (2011) observed that, planting with $0.8 \mathrm{~m}$ distance within trees and $3.5 \mathrm{~m}$ in between rows was superior for maintaining tree vigor and yields under continuous cropping conditions as well as for early recovery from sick soil as compared to 2.0 and $4.0 \mathrm{~m}$ planting distances respectively in fig cultivar 'Masui Dauphine'. Kumar et al., (2014) also noted maximum leaf production, shoot growth, tree height and tree circumference under closer spacing in Deanna fig. Moreover, Mano and Hamada (2005) while studying the beneficial effects of high density planting in fig noted that planting distance with $1.0 \mathrm{~m}$ between tree and $3 \mathrm{~m}$ between rows was superior for early recovery from low temperature injury as well as for better growth and yields.

\section{Physiological parameters}

During rapid vegetative growth, the tree density had significant influence on gas exchange characteristics of exposed leaves in the canopy. Highest photosynthesis rate was observed in T1 and least in T5. Highest transpiration rate was observed in $\mathrm{T} 3$ and least in T5. Highest stomatal conductance was observed in T1 and least in T5. However, in the partially exposed leaves, no significant differences were observed in photosynthesis rate but significant differences were observed in transpiration rate and the stomatal conductance. The tree spacing had no influence on the gas exchange characteristics of the shaded leaves. Overall, the exposed leaves, positioned in periphery of the canopy receiving an average PAR of $1597 \mu \mathrm{mol} \mathrm{m}^{-2}$ $\mathrm{s}^{-1}$ had higher photosynthesis rates. The photosynthesis rate ranged from 13.0 to 15.41 $\mu$ mol $\mathrm{m}^{-2} \mathrm{~s}^{-1}$. Partially shaded leaves, receiving PAR of $475 \mu \mathrm{mol} \mathrm{m} \mathrm{m}^{-2} \mathrm{~s}^{-1}$ had photosynthesis rates in the range of 5.74 to $6.46 \mu \mathrm{mol} \mathrm{m} \mathrm{m}^{-2} \mathrm{~s}^{-1}$ which was around 42 to 44 $\%$ of the fully exposed leaves. The shaded leaves receiving PAR of $102 \mu \mathrm{mol} \mathrm{m}^{-2} \mathrm{~s}^{-1}$ had photosynthesis rates in the range of 2.30 to $3.40 \mu \mathrm{mol} \mathrm{m}^{-2} \mathrm{~s}^{-1}$ which was around $18-22$ $\%$ of the fully exposed leaves, indicating that the higher contribution of photosynthates is from the exposed and partially exposed leaves in the canopy. Even though the shaded leaves received PAR of only $6.4 \%$ of the exposed leaves they were efficient in terms of photosynthesis. Hence in the fig canopy trained to open center, even the shaded leaves placed lower in the canopy contribute to the canopy photosynthesis and productivity. In an orchard system, the amount of PAR intercepted by the tree canopy influences the photosynthesis rate and subsequent growth and productivity. In the present study, the per cent PAR interception by the canopy did not differ significantly among the planting densities (Table 3) where the overall per cent PAR interception by the canopy ranged from 79.37 to $86.63 \%$.

At fruit development stage, tree densities did not have significant influence on the gas exchange characteristics except for the stomatal conductance in the exposed leaves. However, the photosynthesis rates were in the range of 13.82 to $15.52 \mu \mathrm{mol} \mathrm{m} \mathrm{m}^{-2} \mathrm{~s}^{-1}$ in exposed leaves, 5.81 to $6.62 \mu \mathrm{mol} \mathrm{m}^{-2} \mathrm{~s}^{-1}$ in partially exposed leaves and 2.84 to $3.60 \mu$ mol m $\mathrm{m}^{-2} \mathrm{~s}^{-1}$ in shaded leaves where they received PAR of 1313, 231 and $132 \mu \mathrm{mol} \mathrm{m}^{-2}$ $\mathrm{s}^{-1}$, respectively (Table 4 ). The photosynthesis rates were in the range as observed during the vegetative stage, indicating that the leaves actively contribute for the developing fruits. Though the partially shaded and shaded leaves contribute lower photosynthates to the canopy they had lower transpiration rates and thus reduced the water loss. Leaves receiving 
various light intensities in the tree canopy exhibited range of photosynthesis rates; increasing proportional to light intensity till light saturation occurs, after which the rate of photosynthesis becomes more or less constant.

Thus, photosynthesis rates of leaves receiving different light regimes in the canopy and subsequent contribution of photo assimilates influence the tree growth and yield under different planting densities. The present study on gas exchange parameters was restricted to the more vigorous Poona variety as more competition for light was expected in its case.

\section{Fruit yield}

Fruit yield in terms of fruit number, weight of fruits per tree and productivity per hectare were significantly influenced by planting density. Despite the low production efficiency in the initial orchard years when trees were still young, the response to planting density was significant.

Table.1 Effect of tree densities on mean vegetative growth parameters in Poona fig over the period of five years

\begin{tabular}{|c|c|c|c|c|c|c|c|c|}
\hline \multicolumn{3}{|c|}{ Treatment } & \multirow{2}{*}{$\begin{array}{l}\text { Tree } \\
\text { height } \\
\text { (m) }\end{array}$} & \multirow{2}{*}{$\begin{array}{l}\text { No. of } \\
\text { leaves / } \\
\text { shoot }\end{array}$} & \multicolumn{2}{|c|}{$\begin{array}{l}\text { Canopy spread } \\
(\mathrm{m})\end{array}$} & \multirow{2}{*}{$\begin{array}{l}\text { Shoot } \\
\text { length } \\
(\mathrm{cm})\end{array}$} & \multirow{2}{*}{$\begin{array}{l}\text { Trunk } \\
\text { Circumference } \\
(\mathrm{cm})\end{array}$} \\
\hline No. & Spacing & Plants/ha & & & $\mathrm{N}-\mathrm{S}$ & E-W & & \\
\hline T1 & $5.0 \mathrm{~m} \times 2.0 \mathrm{~m}$ & 1000 & 2.47 & 16.19 & 2.51 & 2.20 & 60.47 & 34.64 \\
\hline $\mathrm{T} 2$ & $5.0 \mathrm{~m} \times 2.5 \mathrm{~m}$ & 800 & 2.57 & 17.24 & 2.45 & 2.27 & 65.12 & 36.11 \\
\hline T3 & $5.0 \mathrm{~m} \mathrm{x} 3.0 \mathrm{~m}$ & 666 & 2.29 & 16.88 & 2.37 & 2.21 & 59.00 & 33.39 \\
\hline $\mathrm{T} 4$ & $5.0 \mathrm{~m} \times 3.5 \mathrm{~m}$ & 571 & 2.27 & 15.80 & 2.28 & 2.30 & 59.41 & 34.42 \\
\hline T5 & $5.0 \mathrm{~m} \times 4.0 \mathrm{~m}$ & 500 & 2.28 & 18.37 & 2.06 & 2.12 & 59.31 & 33.56 \\
\hline \multicolumn{3}{|c|}{ F-test } & $*$ & NS & $*$ & NS & NS & NS \\
\hline \multicolumn{3}{|c|}{$\mathrm{SEM} \pm$} & 0.04 & 1.02 & 0.09 & 0.05 & 2.54 & 0.86 \\
\hline \multicolumn{3}{|c|}{ CD 5\% } & 0.13 & - & 0.29 & - & - & - \\
\hline
\end{tabular}

Table.2 Effect of tree densities on mean vegetative growth parameters in Deanna fig over the period of five years

\begin{tabular}{|c|c|c|c|c|c|c|c|c|}
\hline \multicolumn{3}{|c|}{ Treatment } & \multirow{2}{*}{$\begin{array}{l}\text { Tree } \\
\text { height } \\
(\mathrm{m})\end{array}$} & \multirow{2}{*}{$\begin{array}{l}\text { No. of } \\
\text { leaves / } \\
\text { shoot }\end{array}$} & \multicolumn{2}{|c|}{$\begin{array}{l}\text { Canopy } \\
\text { spread (m) }\end{array}$} & \multirow{2}{*}{$\begin{array}{l}\text { Shoot } \\
\text { length } \\
(\mathrm{cm})\end{array}$} & \multirow{2}{*}{$\begin{array}{l}\text { Trunk } \\
\text { Circumference } \\
(\mathrm{cm})\end{array}$} \\
\hline No. & Spacing & Plants/ha & & & $\mathrm{N}-\mathrm{S}$ & E-W & & \\
\hline $\mathrm{T} 1$ & $5.0 \mathrm{~m} \times 2.0 \mathrm{~m}$ & 1000 & 1.96 & 10.23 & 2.48 & 2.19 & 34.23 & 31.49 \\
\hline $\mathrm{T} 2$ & $5.0 \mathrm{~m} \times 2.5 \mathrm{~m}$ & 800 & 1.85 & 12.78 & 2.19 & 1.85 & 33.18 & 31.57 \\
\hline $\mathrm{T} 3$ & $5.0 \mathrm{~m} \times 3.0 \mathrm{~m}$ & 666 & 1.92 & 11.33 & 2.12 & 2.04 & 32.10 & 31.15 \\
\hline $\mathrm{T} 4$ & $5.0 \mathrm{~m} \times 3.5 \mathrm{~m}$ & 571 & 1.85 & 9.83 & 2.22 & 2.17 & 30.70 & 29.25 \\
\hline T5 & $5.0 \mathrm{~m} \mathrm{x} 4.0 \mathrm{~m}$ & 500 & 1.79 & 13.12 & 2.09 & 2.01 & 32.54 & 29.32 \\
\hline \multicolumn{3}{|c|}{ F-test } & NS & $\mathrm{NS}$ & $*$ & $\mathrm{NS}$ & $\mathrm{NS}$ & $*$ \\
\hline \multicolumn{3}{|c|}{$\mathrm{SEM} \pm$} & 0.06 & 0.03 & 0.05 & 0.09 & 1.10 & 0.40 \\
\hline \multicolumn{3}{|c|}{ CD 5\% } & - & - & 0.16 & - & - & 1.20 \\
\hline
\end{tabular}


Table.3 Effect of tree densities on gas exchange parameters

During vegetative growth in Poona fig

\begin{tabular}{|c|c|c|c|c|c|c|c|c|c|}
\hline \multirow[t]{2}{*}{ Treatm-ent } & \multicolumn{3}{|c|}{$\begin{array}{l}\text { Exposed Leaves } \\
\text { (PAR 1597) }\end{array}$} & \multicolumn{3}{|c|}{$\begin{array}{l}\text { Partially Exposed Leaves } \\
\text { (PAR 475) }\end{array}$} & \multicolumn{3}{|c|}{$\begin{array}{l}\text { Shaded Leaves } \\
(\text { PAR 102) }\end{array}$} \\
\hline & $\begin{array}{c}\text { Photo } \\
\text { synthesis } \\
\text { rate }(\mu \mathrm{mol} \\
\left.\mathrm{m}^{-2} \mathrm{~s}^{-1}\right)\end{array}$ & $\begin{array}{c}\text { Transpiration } \\
\left(\mathrm{mmol} \mathrm{m} \mathrm{m}^{-2} \mathrm{~s}^{-}\right. \\
\left.{ }^{1}\right)\end{array}$ & $\begin{array}{c}\text { Stomatal } \\
\text { conductance } \\
\left(\mathrm{mol} \mathrm{m}^{-2} \mathrm{~s}^{-1}\right)\end{array}$ & $\begin{array}{c}\text { Photo } \\
\text { synthesis } \\
\text { rate }(\mu \mathrm{mol} \\
\left.\mathrm{m}^{-2} \mathrm{~s}^{-1}\right)\end{array}$ & $\begin{array}{c}\text { Transpiratio } \\
\mathrm{n}\left(\mathrm{mmol} \mathrm{m}^{-2}\right. \\
\left.\mathrm{s}^{-1}\right)\end{array}$ & $\begin{array}{c}\text { Stomatal } \\
\text { conductance } \\
\left(\mathrm{mol} \mathrm{m}^{-2} \mathrm{~s}^{-1}\right)\end{array}$ & $\begin{array}{c}\text { Photo } \\
\text { synthesis } \\
\text { rate }(\mu \mathrm{mol} \\
\left.\mathrm{m}^{-2} \mathrm{~s}^{-1}\right)\end{array}$ & $\begin{array}{l}\text { Transpiration } \\
\left(\mathrm{mmol} \mathrm{m}^{-2} \mathrm{~s}^{-1}\right)\end{array}$ & $\begin{array}{c}\text { Stomatal } \\
\text { conductance } \\
\left(\mathrm{mol} \mathrm{m}^{-2} \mathrm{~s}^{-1}\right)\end{array}$ \\
\hline $\mathrm{T} 1$ & 15.41 & 8.21 & 0.58 & 5.84 & 3.22 & 0.28 & 3.40 & 2.34 & 0.17 \\
\hline $\mathrm{T} 2$ & 14.78 & 8.67 & 0.47 & 5.88 & 2.90 & 0.17 & 2.30 & 2.73 & 0.18 \\
\hline T3 & 14.38 & 9.45 & 0.39 & 5.74 & 3.48 & 0.16 & 2.43 & 2.80 & 0.18 \\
\hline $\mathrm{T} 4$ & 13.30 & 8.77 & 0.32 & 6.46 & 3.79 & 0.17 & 2.72 & 3.09 & 0.15 \\
\hline T5 & 13.00 & 7.35 & 0.28 & 6.09 & 4.04 & 0.16 & 3.14 & 3.19 & 0.16 \\
\hline F-test & $*$ & $*$ & $*$ & NS & $*$ & $*$ & NS & NS & NS \\
\hline SEM \pm & 0.52 & 6.15 & 0.11 & 0.27 & 0.25 & 0.02 & 0.28 & 0.29 & 0.02 \\
\hline $\mathrm{CD}_{5 \%}$ & 1.03 & 0.35 & 1.62 & 0.79 & 0.08 & - & - & - & - \\
\hline
\end{tabular}

Table.4 Effect of tree densities on gas exchange parameters and light interception During fruit development in Poona fig

\begin{tabular}{|c|c|c|c|c|c|c|c|c|c|c|}
\hline \multirow[t]{2}{*}{ Treatment } & \multicolumn{3}{|c|}{$\begin{array}{l}\text { Exposed Leaves } \\
\text { (PAR 1313) }\end{array}$} & \multicolumn{3}{|c|}{$\begin{array}{l}\text { Partially Exposed Leaves } \\
(\text { PAR 231) }\end{array}$} & \multicolumn{3}{|c|}{$\begin{array}{l}\text { Shaded Leaves } \\
(\mathrm{PAR} \sim 132)\end{array}$} & \multirow{2}{*}{$\begin{array}{l}\text { \%PAR } \\
\text { intercepted } \\
\text { by canopy }\end{array}$} \\
\hline & 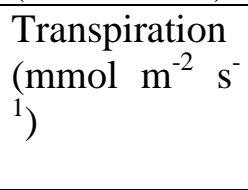 & $\begin{array}{l}\text { Stomatal } \\
\text { conductance } \\
\left(\mathrm{mol} \mathrm{m}^{-2} \mathrm{~s}^{-1}\right)\end{array}$ & $\begin{array}{l}\text { Photo } \\
\text { synthesis } \\
\text { rate }(\mu \text { mol } \\
\left.\mathrm{m}^{-2} \mathrm{~s}^{-1}\right)\end{array}$ & $\begin{array}{l}\text { Transpi } \\
\text { ration } \\
(\mathrm{mmol} \\
\left.\mathrm{m}^{-2} \mathrm{~s}^{-1}\right)\end{array}$ & $\begin{array}{l}\text { Stomatal } \\
\text { conductance } \\
\left(\mathrm{mol} \mathrm{m}^{-2} \mathrm{~s}^{-1}\right)\end{array}$ & \begin{tabular}{|l} 
Photo \\
synthesis \\
rate $(\mu \mathrm{mol}$ \\
$\left.\mathrm{m}^{-2} \mathrm{~s}^{-1}\right)$
\end{tabular} & $\begin{array}{l}\text { Transpiration } \\
\left(\mathrm{mmol} \mathrm{m} \mathrm{s}^{-2}\right. \\
\left.{ }^{1}\right)\end{array}$ & $\begin{array}{l}\text { Stomatal } \\
\text { conductance } \\
\left(\mathrm{mol} \mathrm{m}^{-2} \mathrm{~s}^{-1}\right)\end{array}$ & $\begin{array}{l}\text { Photo } \\
\text { synthesis } \\
\text { rate }(\mu \text { mol } \\
\left.m^{-2} s^{-1}\right)\end{array}$ & \\
\hline $\mathrm{T} 1$ & 5.31 & 0.45 & 15.52 & 2.77 & 0.24 & 6.62 & 3.25 & 0.18 & 3.05 & $83.47(9.13)$ \\
\hline $\mathrm{T} 2$ & 6.20 & 0.41 & 14.50 & 3.30 & 0.22 & 6.54 & 3.14 & 0.19 & 3.70 & $79.37(8.90)$ \\
\hline $\mathrm{T} 3$ & 5.68 & 0.32 & 14.20 & 3.15 & 0.19 & 6.01 & 2.78 & 0.15 & 2.84 & $86.63(9.30)$ \\
\hline $\mathrm{T} 4$ & 5.42 & 0.30 & 13.82 & 3.57 & 0.19 & 5.81 & 2.94 & 0.18 & 3.55 & $81.96(9.04)$ \\
\hline T5 & 5.99 & 0.37 & 14.99 & 3.47 & 0.21 & 5.97 & 2.89 & 0.18 & 3.60 & $83.50(9.13)$ \\
\hline F-test & NS & $*$ & NS & NS & NS & NS & NS & NS & NS & \\
\hline $\mathrm{SEM} \pm$ & 0.27 & 0.02 & 0.39 & 0.21 & 0.01 & 0.38 & 0.19 & 0.01 & 0.30 & NS \\
\hline $\mathrm{CD}_{5 \%}$ & - & 0.07 & - & - & - & - & - & - & - & - \\
\hline
\end{tabular}


Table.5 Effect of tree densities on mean yield and fruit quality in Poona fig and Deanna fig over the period of five years

\begin{tabular}{|l|l|l|l|l|l|l|l|l|}
\hline $\begin{array}{l}\text { Treat- } \\
\text { ment }\end{array}$ & \multicolumn{9}{|l|}{ Poona Fig } & \multicolumn{2}{l|}{ Deanna Fig } \\
\hline & \multicolumn{3}{|l|}{ Yield/tree } & \multicolumn{2}{l|}{ Yield/tree } \\
\hline & $\begin{array}{l}\text { No. of } \\
\text { Fruits }\end{array}$ & $\begin{array}{l}\text { Wt. } \\
(\mathrm{Kg})\end{array}$ & $\begin{array}{l}\text { TSS } \\
\left({ }^{0} \mathrm{~B}\right)\end{array}$ & $\begin{array}{l}\text { Acidity } \\
(\%)\end{array}$ & $\begin{array}{l}\text { No. of } \\
\text { Fruits }\end{array}$ & Wt. (Kg) & TSS $\left.{ }^{0} \mathrm{~B}\right)$ & Acidity $(\%)$ \\
\hline T1 & 328.45 & 14.02 & 21.45 & 0.27 & 189.75 & 12.05 & 17.31 & 0.27 \\
\hline T2 & 319.84 & 13.96 & 21.35 & 0.26 & 173.73 & 10.18 & 17.67 & 0.28 \\
\hline T3 & 299.35 & 13.78 & 21.99 & 0.29 & 176.72 & 9.27 & 17.32 & 0.29 \\
\hline T4 & 313.25 & 13.53 & 20.29 & 0.29 & 219.68 & 9.64 & 17.26 & 0.26 \\
\hline T5 & 243.43 & 11.17 & 20.95 & 0.29 & 191.35 & 8.41 & 17.34 & 0.28 \\
\hline F-test & $*$ & NS & NS & $*$ & $*$ & NS & NS & NS \\
\hline SEM \pm & 13.84 & 1.19 & 0.47 & 0.01 & 10.49 & 1.54 & 0.41 & 0.01 \\
\hline CD $5 \%$ & 41.51 & - & - & 0.01 & 31.46 & - & - & - \\
\hline
\end{tabular}

Table.6 Effect of tree densities on productivity in Poona fig and Deanna fig over the period of five years

\begin{tabular}{|l|l|l|l|l|l|l|l|l|l|l|l|l|l|l|l|}
\hline $\begin{array}{l}\text { Treat } \\
\text { ment }\end{array}$ & \multicolumn{9}{l|}{ Poona Fig } & \multicolumn{3}{l|}{ Deanna Fig } \\
\hline & \multicolumn{9}{|l|}{ Productivity (MT/ha) } \\
\hline & 2011 & 2012 & 2013 & 2014 & 2015 & Mean & $\begin{array}{l}\text { Cumul- } \\
\text { ative }\end{array}$ & 2011 & 2012 & 2013 & 2014 & 2015 & Mean & $\begin{array}{l}\text { Cumula } \\
\text {-tive }\end{array}$ \\
\hline T1 & 8.45 & 14.63 & 15.22 & 16.50 & 15.34 & 14.02 & 70.14 & 5.88 & 16.04 & 8.16 & 7.20 & 9.00 & 9.25 & 46.28 \\
\hline T2 & 6.41 & 12.50 & 10.79 & 11.88 & 14.27 & 11.17 & 55.85 & 3.81 & 12.09 & 6.04 & 6.00 & 8.76 & 7.34 & 36.71 \\
\hline T3 & 3.93 & 11.04 & 7.82 & 9.53 & 13.64 & 9.19 & 45.95 & 2.80 & 9.73 & 8.07 & 4.30 & 6.80 & 6.34 & 31.71 \\
\hline T4 & 4.10 & 8.93 & 6.47 & 7.54 & 11.62 & 7.73 & 38.65 & 1.58 & 8.35 & 6.08 & 4.54 & 6.86 & 5.48 & 27.44 \\
\hline T5 & 2.15 & 7.88 & 4.42 & 6.87 & 6.60 & 5.58 & 27.93 & 0.97 & 7.35 & 5.30 & 3.82 & 5.35 & 4.56 & 22.81 \\
\hline F-test & $*$ & NS & $*$ & NS & $*$ & $*$ & $*$ & NS & NS & NS & NS & $*$ & $*$ & $*$ \\
\hline SEM \pm & 0.05 & 0.22 & 2.46 & 7.30 & 3.10 & 4.40 & 0.54 & 0.35 & 0.13 & 0.11 & 0.28 & 0.52 & 0.52 & 0.52 \\
\hline $\mathrm{CD}_{5 \%}$ & 0.16 & - & 3.71 & - & 1.49 & 1.32 & 1.62 & - & - & - & - & 3.11 & 1.55 & 1.55 \\
\hline
\end{tabular}

In Poona and Deanna fig, the cumulative yield (70.10 MT/ha and 46.28 MT/ha respectively) were highest, under highest tree density of 1000 trees per hectare with mean productivity of 14.02 MT/ha and 9.25 MT/ha respectively (Table 6). More number of fruits and fruit weight per tree were with higher tree densities. This could be due to greater photosynthetic activity and optimum microclimate conditions under closer spacing. Similarly, higher fruit number (133750 / ha), fruit weight $(62 \mathrm{gm})$ and yield $(173.30 \mathrm{q} / \mathrm{ha})$ were reported under closer spacing of $5 \times 2 \mathrm{~m}$ with 4 buds/cane pruning in fig (Kumar et al., 2014). However, Hosomi et al., (2013) reported reduced size and weight of fruit under closer spacing in fig which could be due to change in lighting conditions which affected photosynthesis rate. Further, Mano et al., (2011) perceived that average size of fruits was unaffected by spacing treatments, however maximum mean yields were higher under closer spacing in fig. The trend in terms of mean fruit number was more or less same 
over the period of five years with respect to planting densities studied. However, in Poona fig, maximum mean number of fruits per tree (328.45) and lowest mean number of fruits per tree (243.43) were at tree densities of 1000 plants and 500 plants per hectare respectively. Moreover, in Deanna fig, maximum fruit yield $(12.05 \mathrm{Kg} /$ tree $)$ was noted at higher planting densities of 1000 trees per hectare and followed a declining trend with lower tree densities (Table 5). Based on above findings, higher planting density of 1000 trees or 800 trees per ha could be helpful to obtain higher yields in both Poona and Deanna cultivars.

\section{Fruit quality}

There was no appreciable influence of different planting densities on fruit quality aspects such as total soluble solids and acidity. Fruit quality parameters like TSS and acidity were unchanged at all the tree densities (Table 5). Similarly, other studies in fig (Kumar et al., 2014; Mano and Hamada, 2005; Hosomi et al., 2013) concluded that fruit quality parameters (TSS and titratable acidity) were unaffected by planting distances. However, Mano et al., (2011) noted significant differences in fruit quality parameters under closer planting distances in fig. They reported lower TSS, TA and antioxidants contents at $0.8 \mathrm{~m}$ planting distance compared to 2 and $4 \mathrm{~m}$.

Present study suggests that high density planting of fig varieties Poona and Deanna at 1000 plants per hectare with initial training of trees to open centre frame work and annual pruning of previous season's shoots to the basal six nodes during September is promising for considerable enhancement in fruit productivity during the initial six orchard years under the mild tropical, semi-arid conditions. The enhanced productivity by doubling the planting density from 500 trees per hectare was 2.5 times in case of Poona and twice in case of Deanna.

\section{Acknowledgement}

The support of Director, ICAR-Indian Institute of Horticultural Research and Project Coordinator (Arid Zone Fruits) for the study and the assistance of Mr. TN Nagaraju, Senior technician in recording field observations are acknowledged.

\section{References}

AOAC. 1990. Official Methods of Analysis. Association of Official Analytical Chemists, Washington D.C., USA

Botti, C., Franck, N., Prat, L. and Ioannidis, D. 2003. The effect of climatic conditions on fresh fig fruit yield, quality and type of crop. Acta Horticulturae, 605: 37-42.

Brown, P. H. 1994. Seasonal variations in fig (Ficus carica L.) leaf nutrient concentrations. Hortscience, 29: 871873.

Erez, A., Flaishman, M. and Yablowitz, Z. 2003. Breba production under net: Effect of training system. Acta Horticulturae, 605: 119-123.

Flaishman, M. A., Rover, V. and Stover E. 2008. The fig: botany, horticulture, and breeding. Horticultural Reviews, 34: 113-197.

Hosomi, A., Miwa, Y. and Mano, T. 2013. Shoot Growth and Fruit Production of 'Masui Dauphine' Fig Trees Having High Limb Position with Downward Shoots. Journal of Japanese for Horticultural Science, 82 (3): 215-221.

Iyer, C. P. A. and Kurian, R. M. 2006. High Density Planting in Tropical Fruits. International Book Distributing Co., Lucknow, U.P.

Jackson, J. E. 1980. Light interception and utilization by orchard systems. 
Horticultural Reviews, 2: 208-267.

Kozlowski, T.T. 1992. Carbohydrate sources and sinks in woody plants. Botanical Review, 58:

107-222.

Kumar, R, Ganesh, S., Chitraichelvan, R., Upretti, K. K. and Sulladmath, V. V. 2014. Effect of spacing and pruning on growth, yield and quality of cv. Deanna fig (Ficus carica L.). Journal of Horticultural Sciences, 9(1): 31-37.

Mano, T. and Hamada, K. 2005. Effects of close planting on growth, fruit quality and yield in young fig tree. KinkiChugoku-Shikoku Agricultural Research, 6: 72-75.
Mano, T., Mizuta, Y. and Moriguchi T. 2011. Super-high density planting of fig (Ficus carica L.) for early recovery from sick soil and low temperature injury. HortResearch, 10: 367-373.

Melgarejo, P., Martinez, J. J., Hernández, F., Salazar, D. M. and Martinez, R. 2006. Preliminary results on fig soilless culture. Scientia Horticulturae, 111: 255-259.

Nath, V., Kumar, D. and Pandey, V. 2008. Fig. Fruits for the future, pp 512, Vol. 1, Satish Serial Publishing House, Azadpur, Delhi.

\section{How to cite this article:}

Chithiraichelvan, R., Reju M. Kurian, Chandrakant M. Awachare and Laxman, R.H. 2017. Performance of Fig (Ficus carica L.) Under Different Planting Densities. Int.J.Curr.Microbiol.App.Sci. 6(6): 2603-2610. doi: https://doi.org/10.20546/ijcmas.2017.606.311 